\title{
Chris T. Bolliger: An Obituary
}

After an acute illness Chris T. Bolliger, Director and Head of the Respiratory Research Unit and Cohead of the Division of Pulmonology of the Department of Medicine of the University of Stellenbosch, Capetown, South Africa, died on November 2, 2012, at the age of 62.

With him, we have lost an experienced medical doctor as well as a friend. His great expertise and humanity towards his patients and colleagues will be sorely missed.

Chris T. Bolliger was born in Switzerland. He went to medical school in Basel and Lausanne and graduated in 1976. Subsequently he finished his residency and fellowship in internal medicine with a subspecialty in pulmonology. He moved to South Africa in the early 1980s and earned a Baccalaureus with Honors (Hon. BsC) in epidemiology at the University of Stellenbosch in 1989. He then went back to Switzerland in the same year and became a consultant in the Division of Pulmonology of the University Hospital of Basel. During that time, he finished his $\mathrm{PhD}$ and obtained his associate professorship.

In 1999, he moved back to the Faculty of Health Sciences of the University of Stellenbosch, where he was appointed cochairman of the Pulmonology Division and director of the Respiratory Research Unit. In both his research and his clinical work, he set very high standards for himself and those working with him. Most recently, he was the director and head of the Respiratory Research Unit of the Department and cohead of the Division of Pulmonology of the Department of Medicine of the University of Stellenbosch.

From the beginning he developed an ongoing interest in clinical and basic research. Initially he focused on thoracic oncology with special emphasis on interventional

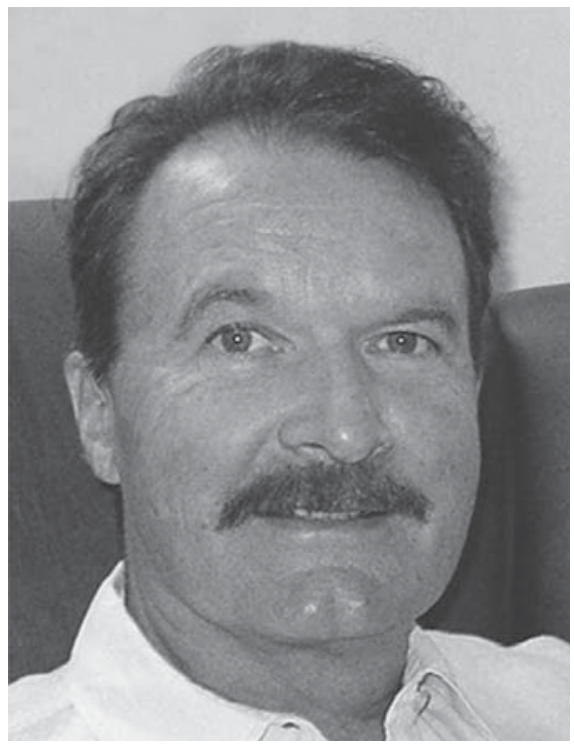

Christoph T. Bolliger, 1950-2012.

bronchoscopy and thoracoscopy, both diagnostic and therapeutic. Other interests of his were cardiopulmonary exercise testing and tobacco control with emphasis on smoking cessation. Over time, he published more than 250 articles, 14 books, and various book chapters. One of his initial publications [1] remains the basis of our daily treatment decisions in lung cancer patients.

In addition to all of his clinical and research work, in 1998 he took over the position of editor-in-chief of Respiration. In the following years, he developed the journal

\section{KARGER}

Fax +41613061234 E-Mail karger@karger.ch www.karger.com
(C) 2012 S. Karger AG, Basel 
into one of the leading publications in the pulmonary community. In the same year, he introduced the very successful Thematic Review Series and in 2001 he launched the Interventional Pulmonology section. In 2002, Respiration became the official journal of the European Association for Bronchology and Interventional Pulmonology. The number of issues grew from 6 to 8 per year in 2008 and again from 8 to 12 issues per year in 2010, and the impact factor of the journal rose from 0.36 to 2.543 .

Additionally, he issued Progress in Respiratory Research, a very successful book series.

With his work, he improved our diagnostic and therapeutic possibilities. He was also an active researcher [2]. $\mathrm{He}$ and his team started the first ever international clinical study to evaluate the use of real-time technology to track lung tumors during radiation delivery. This pioneering work culminated in a first-in-man publication [3].

Besides his clinical and research activities, he was also politically active. He held an officer position in the European Respiratory Society until 2006. In 2002, he was one of the founders of the European Association for Bronchology and Interventional Pulmonology. He served enthusiastically for several years on the board of directors. From 2006 to 2012, he was president of the society. During this time, he worked hard to develop the small society into a well-recognized scientific community and to inte- grate the interventional pulmonology procedures into the general context of the pulmonary diseases specialty, contributing to the realization of specific pathways and models of care for different respiratory pathological conditions.

The list of accomplishments in this obituary highlights the major events in his career, but it is not able to capture all of his professional creativity.

Chris T. Bolliger was not only an excellent doctor, scientist, teacher, and mentor, but he was also an extraordinary friend to all of us.

We will not forget his acute, bright, lively, and likeable glance that expressed an extraordinary enthusiasm, a strong passion for his work, an intellectual curiosity, and a tremendous energy that were transmitted to all who had the fortune to know him.

The community has lost a leader in the field, far too early and unexpectedly. His untimely death did not befit his young mind and soul, his endless energy and enthusiasm. We are deeply saddened and shocked. Nevertheless, we must accept this reality. It is up to us to carry on his work and dreams. In so doing, we will also keep him alive in our minds.

In memory of Chris. Felix J.F. Herth, Heidelberg Stefano Gasparini, Ancona

\section{References}

1 Bolliger CT, Jordan $\mathrm{P}$, Solèr $\mathrm{M}$, Stulz $\mathrm{P}$, Grädel E, Skarvan K, Elsasser S, Gonon M, Wyser C, Tamm M, et al: Exercise capacity as a predictor of postoperative complications in lung resection candidates. Am J Respir Crit Care Med 1995;151:1472-1480.

2 Carr IM, Koegelenberg CF, von GrooteBidlingmaier F, Mowlana A, Silos K, Haverman T, Diacon AH, Bolliger CT: Blood loss during flexible bronchoscopy: a prospective observational study. Respiration 2012;84: 312-318.

3 Bolliger CT, Nader D, Herth F, Chen A, Paris G, Zimmermann F, Gompelmann D, Payne M, Parikh P, Tamm M: Prospective international trial of endobronchial implantation of electromagnetic fiducials for real-time tracking of lung tumors during radiotherapy (RT). Eur Respir J 2012; 40:S56:P1389. 